Інноватика у вихованні. Випуск 11. Том 1. 2020.

УДК 37.01

DOI: $10.35619 /$ iiu.v1i11.262

Лісова Світлана

доктор педагогічних наук, професор, завідувачка кафедри теорії і методики професійної освіти

Рівненського державного гуманітарного університету,

м. Рівне, Україна

ORCID: 0000-0002-6230-0805

e-mail: lisovasvval@gmail.com

\title{
УЗАГАЛЬНЕННЯ ТА СИСТЕМАТИЗАЦІЯ ПЕДАГОГІЧНИХ ЗНАНЬ У ПРОЦЕСІ ПРОФЕСІЙНОЇ ПІДГОТОВКИ МАЙБУТНІХ УЧИТЕЛІВ ТЕХНОЛОГІЙ
}

Анотація. Проведено аналіз наукових досліджень 3 проблеми систематизації педагогічних знань у системі фахової підготовки майбутніх учителів технологій, розглянуто комплексний характер професійно-педагогічної підготовки. Проаналізовано специфіку складових фахової підготовки майбутніх учителів технологій; з огляду на специфіку навчання у ЗВО розкрито етапи становлення фахівця. Здійснено аналіз сучасних тенденцій навчання у ЗВО, специфіки форм організації освітнього процесу. Розкрито освітні цілі професійної підготовки майбутнього вчителя, які розглянуті в єдності з розвивальними і допомагають оволодіти педагогічною майстерністю. Проаналізовано умови організації освітнього процесу, що визначаються психологічними, дидактичними аспектами активізації освітньої діяльності. Обгрунтовано класифікацію пізнавальної діяльності студентів у єдності їі типів. Здійснено аналіз контрольно-регулятивного компоненту дидактичних структур, що припускає використання якісних i кількісних характеристик ефективності пізнавальної діяльності студентів. 3 позиції особистісно орієнтованого навчання розкрито характеристики, що відображають реалізацію особистістю можливостей та ступінь прояву творчості у процесі фахової підготовки. Розглянуто значення здатності до рефлексії, що відіграє велику роль у професійній діяльності майбутнього вчителя; умови формування рефлексії у процесі здійснення фахової підготовки.

Ключові слова: вчитель технологій, навчальний процес, фахова підготовка, пізнавальна діяльність, дидактичні аспекти, узагальнення, систематизація.

Постановка проблеми. Фахова підготовка майбутніх учителів технологій - це спеціально організований навчальний процес у закладі професійної освіти, що спрямований на розв'язання цілей та завдань освітнього стандарту і досягнення заданої якості підготовки випускника (бакалавра); це частина загальної підготовки, яка передбачена навчальними планами спеціальності або напряму підготовки. Головним результатом фахової підготовки майбутніх учителів технологій $є$ їх готовність до самостійної професійної діяльності. В освітньому процесі вищої школи дисципліни і види навчання групуються навколо фахових навчальних предметів. Вимоги, які висувають ці предмети до рівня кваліфікації фахівців, визначають зміст, обсяг, методи і засоби навчання 3 профілюючих дисциплін, впливають на формування цілей і завдань підготовки фахівця, його теоретичної та практичної компетентності. 
Оптимізація професійної підготовки майбутніх учителів технологій, розробка змісту спеціальної підготовки майбутнього вчителя технологій (наприклад, обробка тканини i харчових продуктів), що включає комплекс технікотехнологічних знань, умінь і навичок, неможливі без визначення критеріїв ефективності їх професійної підготовки.

Педагогічна наука вирішує важливе завдання узагальнення та систематизації педагогічних знань майбутніх вчителів, обгрунтування засобів їх удосконалення.

Аналіз останніх досліджень 3 проблеми. Розпочатий різними вченими пошук найбільш ефективних форм систематизації педагогічних знань майбутніх учителів (закономірні основи навчального процесу у вищій школі (Архангельський, 1980); проблеми формування у студентів самостійного мислення (Бондаревський, 1972); контекстне навчання, що являє собою реалізацію динамічної моделі розвитку діяльності студентів, а саме: від навчальної діяльності через навчально-професійну до власне професійної діяльності (Вербицький, 2010), а також теоретичні основи особистісно орієнтованого навчання у середній школі (Якиманська, 1996, Сєріков, 1994, Чобітько, 2007 та ін.) можуть бути використані як наукова база для структурування процесу навчання майбутніх учителів технологій.

Взаємозв'язку загальноосвітньої та професійної підготовки присвячені праці А. Бєляєвої (1989), М. Берулава (2000), М. Махмутова (1975); міждисциплінарним підходам дослідження - Е. Вєліхова (1988), В. Зінченка (1988); питанням взаємозв'язку гуманітаризації та інтеграції освіти присвячені наукові дослідження В. Розумовського (1988), Л. Тарасова (1988), В. Андрущенка (2000). Проблемам розвитку педагогічної майстерності у структурі фахової підготовки вчителя - праці вітчизняних на зарубіжних дослідників І. Зязюна (2008), Л. Крамущенка (2008), В. Сидоренка (2015), П. Матвієнко (2006) та ін.

Мета статті - визначити місце системи педагогічних знань у структурі фахової підготовки, обгрунтувати послідовність узагальнення та систематизації педагогічних знань у процесі фахової підготовки майбутніх учителів технологій.

Виклад основного матеріалу дослідження. Професійно-педагогічна підготовка майбутніх учителів являє собою сукупність взаємопов'язаних компонентів, які відображають певну освітню систему, спрямовану на формування в них важливих професійних якостей відповідно до соціального замовлення. На нашу думку, професійно-педагогічна підготовка повинна носити комплексний характер, з метою:

1) гармонізувати різні дидактичні компоненти процесу навчання;

2) вирізнити найбільш важливі 3 них для досягнення поставленої дидактичної мети;

3) розглянути ці компоненти у взаємозв'язку з якомога більшою кількістю чинників освітнього процесу, що значно відрізняються за своєю якісною природою й істотно впливають на його результати;

4) виявити взаємозв'язки характеристик структури процесу навчання 3 оцінками його ефективності, які можуть визначати сутність дидактичних закономірностей тощо.

Процес навчання у ЗВО визначається його специфікою, обумовленою цілями професійної підготовки студентів. Загалом, складовими фахової підготовки майбутнього вчителя $\epsilon$ такі уміння:

- вирішувати завдання, що відповідають його кваліфікації;

- здійснювати процес навчання учнів загальноосвітньої школи 3 орієнтацією на завдання навчання, виховання й розвиток особистості школяра та з урахуванням специфіки дисципліни, що викладається; 
Інноватика у вихованні. Випуск 11. Том 1. 2020.

- стимулювати розвиток позаурочної діяльності учнів з урахуванням психолого-педагогічних вимог до освіти і навчання;

- аналізувати власну діяльність 3 метою їі вдосконалення і підвищення своєї кваліфікації.

Досягнення цілей фахової підготовки майбутніми вчителями технологій $€$ складним процесом, що повинен бути адекватний ідеям сучасних дидактичних концепцій. 3 огляду на специфіку навчання у 3ВО умовно можна виділити три етапи становлення фахівця.

Перший етап - адаптація студентів до умов освітнього процесу у ЗВО. На цьому етапі здійснюється надолуження прогалин у знаннях недавніх випускників шкіл, пристосування до способів організації навчальної роботи, характерних для 3BO.

Другий етап - активне освоєння таких способів й оволодіння методологічними уміннями й навичками.

Tретій eman - професійна орієнтація студентів, що вимагає включення додаткових компонентів у процес навчання (наприклад, виробничої практики) i надання професійної спрямованості іншим формам і методам навчання.

Крім того, специфіка навчання у ЗВО проявляється й у формах організації навчального процесу: лекціях, семінарських, індивідуальних заняттях і ін. Чимало часу припадає і на самостійну роботу студентів.

Сучасні тенденції навчання у ЗВО пов'язані зі скороченням аудиторних занять і збільшенням часу на самостійну роботу студентів. У таких умовах предметом особливої турботи стає якість їхньої спеціально-предметної підготовки, оскільки, 3 одного боку, дефіцит аудиторних занять змушує підвищувати темп вивчення матеріалу 3 одночасною його концентрацією, а 3 іншого боку, самостійне опрацювання викликає серйозні труднощі у студентів. У цьому зв'язку виникає проблема пошуку раціональних методів викладання навчальних дисциплін, спрямованих на досягнення гармонійної єдності аудиторних і позааудиторних форм занять. Останні можуть бути ефективно використані для додаткового осмислення студентами у всіх деталях предметних структур, розглянутих на лекціях і тренінгах, а також методів розв'язання завдань, які досліджувалися на практичних заняттях.

Професійна підготовка майбутнього вчителя вимагає також цілеспрямованого розвитку його особистості, формування здібностей, що допомагають оволодіти педагогічною майстерністю. Тому освітні цілі необхідно розглядати в єдності 3 розвивальними. Досягнення останніх припускає певну специфіку реалізації дидактичних структур (стимулюючо-мотивачійних, контрольно-регулювальних, операційно-діяльнісних, рефлексивних).

Стимулюючо-мотиваційний компонент повинен відображати взаємозв'язок дисципліни 3 конкретними сферами майбутньої професійної діяльності. Суб'єктивний досвід корисно поєднувати з реальною педагогічною практикою. Особливу роль має відігравати педагогічна підтримка, форма якої повинна відповідати віковим особливостям студентів, а за змістом - бути методологічною допомогою, що стимулює їх пізнавальну активність.

Умови організації навчального процесу визначаються психологічними, дидактичними аспектами активізації навчальної діяльності. Під психологопедагогічними умовами активізації пізнавальної діяльності студентів розуміємо таке оточення (середовище), у якому в тісній взаємодії представлена найкраща сукупність психологічних і педагогічних факторів (відносин, засобів тощо), що забезпечує можливість викладачеві організувати активну навчальну діяльність 
студентів. Таке середовище створюється 3 урахуванням фізіології, психології особистості, вимог педагогіки до організації процесу навчання і виховання. Ця сукупність факторів визначає взаємозалежність у навчальному процесі фізіологічних, психологічних, педагогічних та інших явищ.

Психолого-педагогічні умови, необхідні для ефективної роботи 3 активізації навчальної діяльності студентів визначимо як:

- забезпечення єдності освітнього, розвивального й виховуючого завдання процесу навчання;

- педагогічно правильне використання принципів дидактики: науковості, зв'язку теорії з практикою, активності й свідомості, індивідуального підходу, проблемності, професійної спрямованості навчання, зв'язку навчальної роботи з науковою діяльністю студентів;

- забезпечення емоційності навчання й створення сприятливої атмосфери;

- динамічність, розмаїтість методів, прийомів, засобів навчання (викладання й навчання), їхня спрямованість на розвиток активної дослідницької діяльності студентів;

- $\quad$ орієнтування студентів на систематичну самостійну роботу над матеріалом у позааудиторний час i правильна організація самостійної роботи, забезпечення регулярності, підвищення ефективності контролю й оцінки знань, умінь і навичок (особливо поточного контролю);

- комплексне, педагогічно спрямоване використання сучасних технічних засобів;

- $\quad$ використання системи психологічних і педагогічних стимуляторів активної навчальної, наукової діяльності студентів.

Стимулювання покликане інтенсифікувати процес засвоєння знань, їх самостійний пошук. Стимул визначається як засоби, що спонукають людей до посиленої діяльності, своєрідний зовнішній поштовх, вагомість якого зростає пропорційно суспільній значущості. Стимули, впливаючи на систему мотивів, виконують роль прискорювачів динаміки потреб, вони ніби $є$ їх природними невід'ємними супутниками. Своєю чергою, потреби під впливом певних стимулів відповідно до матеріальних і духовних потреб суспільства в конкретно історичних соціальних умовах можуть створюватися цілеспрямовано.

Стимули, що використовуються в педагогічному процесі, можуть бути соціальними, психолого-педагогічними тощо. Психолого-педагогічні стимули бувають зовнішні і внутрішні, у педагогічному процесі вони взаємозалежні. Стимулювання в навчальному процесі спрямоване на будь-яке спонукання інтелектуальних, творчих чинників i можливостей, обов'язковою умовою якого $є$ врахування психічних можливостей, рівня підготовленості, вікових особливостей студентів.

Дієвість стимулів залежить і від врахування викладачем низки факторів: а) ставлення студента до обраної спеціальності, до даної науки; б) до викладача; в) до своїх навчальних обов'язків; г) до групи, інших студентів тощо.

Зовнішні стимули в педагогічному процесі діють через внутрішні. До зовнішніх стимулів можна віднести адміністративні впливи деканату, вимоги викладача, товариша, заохочення, покарання й т.п. Якщо студентами керують тільки, або в основному, зовнішні стимули, то навчання буде носити вимушений, примусовий характер. У цьому випадку студент часто звертається до зовнішніх факторів усунення конфлікту: спроба вивчити матеріал шляхом механічного запам'ятовування, використання шпаргалки, переписування у товариша готових висновків лабораторних і практичних робіт або способів розв'язування завдань. 
До внутрішніх стимулів відносяться такі, які мобілізують вольові, розумові процеси особистості. Наприклад, інтерес до знань, внутрішнє прагнення до розширення, поглиблення знань, допитливість тощо. Внутрішні стимули не призведуть до зовнішнього конфлікту i $\epsilon$ найбільш оптимальними як 3 психологічної, так і з педагогічної точки зору.

Операційно-діяльнісний компонент пов'язаний з виконанням студентами різних видів дій. Класифікація пізнавальної діяльності студентів містить вісім ії типів: 1) за зразком; 2) за інструкцією; 3) реконструктивні дії (пропускають пункти інструкції, непотрібні для розв'язання даного завдання); 4) варіативні (частковопошукові) дії; 5) конструктивні дії (ширше - зона дії), які актуалізуються для пошуку узагальненого плану розв'язання класу завдань; 6) евристичні дії; 7) інтуїтивні дії (використовуються при розв'язанні творчих, складних завдань, у яких $\epsilon$ елемент несподіванки, незвичайності); 8) узагальнені дії, що мають всі характеристики перерахованих вище дій, а також здатність до саморозвитку в процесі навчання.

Дії студентів важливо орієнтувати на оволодіння методологією пізнавальної діяльності не тільки для того, щоб підвищити їх успішність, але й для того, щоб студенти надалі могли навчити своїх майбутніх учнів.

Контрольно-регулятивний компонент припускає використання різних характеристик ефективності пізнавальної діяльності студентів. Серед них виділяються якісні і кількісні.

До якісних характеристик відносяться:

а) змістовно-відтворювальний рівень: повнота (у пізнанні об'єкта); узагальненість (у пізнанні його сутності); системність (у пізнанні зв'язків і відносин);

б) рівень, що діяльнісно перетворює: міџність, мобільність, дієвість знань;

в) діяльнісно-особистісний рівень - глибина знань.

Повнота описує результат відтворення студентом відомих характеристик об'єкта вивчення, згідно яких визначається його сутність. У результаті студент уміє розпізнавати об'єкт серед інших.

Узагальненість описує результат відтворення й пояснення сутності об'єкта зі зв'язку його ознак.

Системність характеризує результат відтворення сутності зв'язків і відносин двох або кількох пізнавальних об'єктів і на цій основі - цілісності їхньої організації й функціонування. Виражається вона через зв'язок усіх частин - генетичну основу, закон, загальний механізм тощо.

Міцність характеризує результат запам'ятовування, утримання й збереження в пам'яті повного, узагальненого або систематизованого знання.

Мобільність (готовність) знань визначається результатом їхнього перетворення в процесі застосування у знайомому для студентів середовищі.

Дієвість свідчить про застосування знань у новій ситуації.

Глибина характеризує результат застосування знань, отриманих при вивченні предмета, в життєвій ситуації, практичній діяльності, особистій поведінці на основі усвідомленого ставлення до значущості отриманого знання. Про глибину знань свідчать внутрішні спонукальні мотиви й переконання студентів.

3 позиції особистісно орієнтованого навчання варто розглядати характеристики, що відображають реалізацію особистістю своїх можливостей, ступінь прояву творчості.

У професійній діяльності майбутнього вчителя великого значення набуває здатність до рефлексії. Згідно поглядів А. Реана (1983) та Г. Сухобської (2002), чим більша 
рефлексія суб'єкта діяльності, тобто здатність їі до самоаналізу професійної діяльності, тим вища педагогічна майстерність. Рефлексивні процеси виявляються: у взаємодії вчителя з учнями, у проєктуванні діяльності учнів, у самоаналізі й самооцінці вчителем результатів власної діяльності й навчання учнів способам самоаналізу й самоконтролю, у формуванні потреби вчителя до професійної самоосвіти.

Відсутність рефлексивних умінь студентів сприяє:

- розвитку авторитарного стилю їхнього спілкування, а згодом перенесенню його в майбутню професійну діяльність;

- недостатньому розвитку теоретичного мислення, що означає неякісну професійну (предметну) підготовку впродовж навчання у 3ВО;

- низькому рівню готовності до аналізу власної діяльності, а саме: саморозвитку і рівню професіоналізму.

Формування рефлексії студентів відбувається у процесі набуття ними власного досвіду за допомогою різноманітних форм і прийомів навчання. До них можна віднести такі:

- здійснення студентами аналізу власної навчальної діяльності;

- можливість вибирати завдання різного ступеня складності відповідно до власних уявлень студентів про їх пізнавальні здібності;

- систематичне самооцінювання студентами результатів власної пізнавальної діяльності тощо.

Основною складовою фахової підготовки майбутніх вчителів технологій $є$ : їх теоретична та практична підготовка в процесі навчальних занять 3 циклу загальнотехнічних дисциплін, всіх видів навчально-виробничої практики та факультативних занять; формування в студентів системи базових загальнотехнічних знань, умінь, навичок; засвоєння ними методологічних особливостей викладання спеціальних дисциплін та оволодіння основними методами педагогічної науки.

Висновки i перспективи подальших розвідок. Узагальнення та систематизація педагогічних знань майбутніх вчителів технологій у процесі навчання відбувається шляхом структуризації, утворюючи систему з:

- $\quad$ фундаментальних структур, що відображають сутність процесу пізнання моделювання структур предмета вивчення у сприйнятті студентів. У цьому зв'язку на перший план виступають структури, обумовлені методами організації їхньої пізнавальної діяльності;

- структур, що забезпечують особистісну спрямованість процесу навчання;

- $\quad$ структур, що сприяють формуванню професійно важливих умінь і якостей (професійну компетентність) майбутніх фахівців

Зазначена специфіка фахової підготовки майбутніх вчителів технологій враховувалася нами при розробці різних варіантів структурування й вибору адекватних способів забезпечення особистісної спрямованості.

У розробці цих варіантів необхідно здійснити структурування з огляду на характер навчання як процесу пізнання, його особистісну спрямованість і мету професійної підготовки студентів, у даному випадку - педагогічну. Складність взаємозв'язків компонентів навчального процесу у ЗВО, їх ієрархічність і якісна розмаїтість вимагають реалізації системного підходу до структурування навчання у ЗВО. Сформувалися певні розбіжності між соціальним значенням удосконалення якості підготовки педагогічних кадрів та рівнем розв'язання проблем теоретичної і професійної підготовки вчителя. У перспективі необхідно більш глибоко теоретично осмислити нові проблеми, що виникають у процесі теоретичної та практичної підготовки студентів до педагогічної діяльності. 


\section{СПИСОК ВИКОРИСТАНИХ ДЖЕРЕЛ}

Архангельский, С. (1980). Учебный процесс в высшей школе, его закономерные основы и методы. Москва: Высшая школа, 368 с.

Бондаревский, В. (1972). Процесс вузовского обучения и проблемь формирования у студентов самостоятельного мышления и научных интересов. Преподавание педагогических дисциплин в высшей школе. Москва: Высшая школа. Т.2., с. 57-85.

Вербицкий, В. (2010). Активное обучение в высшей школе: контекстный подход. Москва.: Логос, 207 с.

Якиманская, И. (1996). Личностно-ориентированное обучение в современной школе. Москва: Педагогика, 96 с.

Сериков, В. (1994). Личностный подход в образовании: конщеепция $и$ технологии: монография. Волгоград: Перемена, 152 с.

Чобітько, М. (2007). Теоретико-методологічні засади особистісно орієнтованої професійної підготовки майбутніх вчителів: Доктор педагогічних наук. Київ, 43c

Бєляєва, А. (1989). Інтеграційні процеси в змістовному компоненті професійного навчання. Наукові основи процесу професійного навчання в середніх профтехучилищах: зб.наук.пр. ВНП профтехосвіти. Львів, с 57-59.

Берулава, М. (2000). Теория и практика гуманизаџии образования. Москва: «Гельнос АРВ», 336 с.

Махмутов, М. (1975). Проблемное обучение. Москва: Педагогика, 255 с.

Велихов, Е., Зинченко, В., Лекторский В. (1988). Сознание: опыт междисциплинарного похода. Вопросы философии, № 11, с. 3-30.

Разумовский, В., Тарасов, Л. (1988). Развитие общего образования: интеграция и гуманитаризация. Педагогика. № 7, с. 28-40.

Андрущенко, В. (2000). Наукове проектування інноваційних та альтернативних систем вищої освіти: Збірник матеріалів до Всеукраїнської науково-практичної конферениї. 11-12 травня 2000 р. / В.П. Андрущенко та ін. (ред.). Інститут вищої освіти АПН України, Тернопільська академія народного господарства. Тернопіль: Економічна думка. 224 с., с.18.

Зязюн, І. та Крамущенко, Л. (2008). Педагогічна майстерність: підручник. 3-тє вид., допов. і переробл. Київ: СПД Богданова А. М. 376 с.

Сидоренко, В. (2015). Феноменологія педагогічної майстерності вчителя. Педагогічна творчість, майстерність, професіоналізм у системі підготовки освітянських кадрів: здобутки, пошуки, перспективи: монографія / кер. авт. кол. Н.В. Гузій; Мін-во освіти і науки України, Нац. пед. ун-т імені М. П. Драгоманова. Київ: НПУ імені М. П. Драгоманова, с. 156-199.

Матвієнко, П. (2006) Удосконалення педагогічної майстерності в умовах особистісно-зоріснтованої освіти: модульний посібник. Полтава: ПОІППО, 292 с.

Реан, А. (1983). Психолого-педагогический анализ проблемы выбора методов обучения в высшей школе: Кандидат педагогических наук. Лененград, 199 с.

Сухобская, Г. и Соколовская, Е. (2002). Андрагогическое обеспечение развития образования взрослых в современном обществе как проблема научного исследования. Проблемы формирования педагогической компетентности специалистов постдипломного образования. Санкт-Петербург, с. 10-12.

\section{REFERENCES}

Arkhangelskii, S. (1980). Uchebnyi protsess v vysshei shkole, ego zakonomernye osnovy $i$ metody [The Educational Process in Higher Education, Its Regular Principles and Methods]. Moskva: Vysshaya shkola, 368 s. (in Russian) 
Bondarevskii, V. (1972). Protsess vuzovskogo obucheniya i problemy formirovaniya $u$ studentov samostoyatelnogo myshleniya $i$ nauchnykh interesov. Prepodavanie pedagogicheskikh distsiplin v vysshei shkole [The Process of University Education and the Problems Shaping Independent Thinking and Scientific Interests for Students]. Moskva: Vysshaya shkola. T.2., s. 57-85. (in Russian)

Verbitskii, V. (2010). Aktivnoe obuchenie v vysshei shkole: kontekstnyi podkhod [Active Learning in Higher Education: Contextual Approach]. Moskva: Logos, 207 s. (in Russian)

Yakimanskaya, I. (1996). Lichnostno-orientirovannoe obuchenie $v$ sovremennoi shkole [Student-centered Learning in Modern School]. Moskva: Pedagogika, 96 s. (in Russian)

Serikov, V. (1994). Lichnostnyi podkhod v obrazovanii: kontseptsiya i tekhnologii: monografiya [Personal Approach to Education: Concept and Technology]. Volgograd: Peremena, 152 s. (in Russian)

Chobitko, M. (2007) Teoretyko-metodolohichni zasady osobystisno oriientovanoi profesiinoi pidhotovky maibutnikh vchyteliv [Theoretical and Methodological Principles of Personality-oriented Professional Training of Future Teachers]: Doctor of pedagogical sciences/ Kyiv. 43 s. (in Ukrainian)

Bieliaieva, A. (1989) Intehratsiini protsesy v zmistovnomu komponenti profesiinoho navchannia [Integration Processes in the Content Component of Vocational Training]. Naukovi osnovy protsesu profesiinoho navchannia $v$ serednikh proftekhuchylyshchakh: zb.nauk.pr. VNP proftekhosvity. Lviv. S 57-59. (in Ukrainian)

Berulava, M. (2000). Teoriya i praktika gumanizatsii obrazovaniya [Theory and Practice of Humanization of Education]. Moskva: "Gelnos ARV", 336 s. (in Russian)

Makhmutov, M. (1975). Problemnoe obuchenie [Problem Learning]. Moskva: Pedagogika, 255 s. (in Russian)

Velikhov, E., Zinchenko, V., Lektorskii V. (1988). Soznanie: opyt mezhdistsiplinarnogo pokhoda [Consciousness: Interdisciplinary Experience]. Voprosy filosofii, No 11, s. 3-30. (in Russian)

Razumovskii, V. \& Tarasov, L. (1988). Razvitie obshchego obrazovaniya: integratsiya i gumanitarizatsiya [The Development of General Education: Integration and Humanitarianization] Pedagogika. No 7, s. 28-40. (in Russian)

Andrushchenko, V. (2000). Naukove proektuvannia innovatsiinykh ta alternatyvnykh system vyshchoi osvity [Scientific Design of Innovative and Alternative Systems of Higher Education]: Zbirnyk materialiv do Vseukrainskoi naukovo-praktychnoi konferentsii. 11-12 travnia 2000 r. / V.P. Andrushchenko ta in. (red.) Instytut vyshchoi osvity APN Ukrainy, Ternopilska akademiia narodnoho hospodarstva. Ternopil: Ekonomichna dumka. 224 s., s.18. (in Ukrainian)

Ziaziun, I., Kramushchenko, L. (2008). Pedahohichna maisternist [Pedagogical Skills]: pidruchnyk. 3-tie vyd., dopov. i pererobl. Kyiv: SPD Bohdanova A. M. 376 s. (in Ukrainian)

Sydorenko, V. (2015) Fenomenolohiia pedahohichnoi maisternosti vchytelia [Phenomenology of Pedagogical Skill of a Teacher]. Pedahohichna tvorchist, maisternist, profesionalizm u systemi pidhotovky osvitianskykh kadriv: zdobutky, poshuky, perspektyvy : monohrafiia / ker. avt. kol. N.V. Huzii; Min-vo osvity i nauky Ukrainy, Nats. ped. un-t imeni M. P. Drahomanova. Kyiv: NPU imeni M.P. Drahomanova. s. 156199.(in Ukrainian)

Matviienko, P. (2006) Udoskonalennia pedahohichnoi maisternosti $v$ umovakh osobystisno-zoriientovanoi osvity [Improving Pedagogical Skills in the Context of 
Personality-oriented Education]: modulnyi posibnyk Poltava: POIPPO. 292 s. (in Ukrainian)

Rean. A. (1983). Psikhologo-pedagogicheskiy analiz problemy vybora metodov obucheniya $v$ vysshey shkole [Psychological and Pedagogical Analysis of the Problem of Choosing Teaching Methods in Higher Education]: Kandidat pedagogicheskikh nauk. L. 199 s. (in Russian)

Sukhobskaya, G. \& Sokolovskaya, E. (2002). Andragogicheskoe obespechenie razvitiya obrazovaniya vzroslykh v sovremennom obshchestve kak problema nauchnogo issledovaniya. [Andragogical Support for the Development of Adult Education in Modern Society as a Problem of Scientific Research]. Problemy formirovaniya pedagogicheskoi kompetentnosti spetsialistov postdiplomnogo obrazovaniya. Sankt-Peterburg, s 10-12. (in Russian)

\title{
GENERALIZATION AND SYSTEMATIZATION OF PEDAGOGICAL KNOWLEDGE IN THE PROCESS OF VOCATIONAL TRAINING OF FUTURE TECHNOLOGIES TEACHERS
}

Svitlana Lisova Doctor of Sciences (in Pedagogy), Professor, Head at the Department of Theory and Methods of Vocational Education, Rivne State University for the Humanities, Rivne, Ukraine ORCID: 0000-0002-6230-0805 e-mail: lisovasvval@gmail.com

\begin{abstract}
The analysis of scientific researches on the issue of systematization of pedagogical knowledge in the system of vocational training of future technologies teachers was carried out, the complex character of vocational and pedagogical training was considered. The specifics of the components of vocational training of future technologies teachers were analyzed; taking into account the specifics of higher education, the stages of becoming a specialist were revealed. The analysis of modern tendencies of training in high school, specificity of forms of the organization of educational process were carried out. The educational goals of vocational training of the future teacher were revealed, which are considered in unity with the developmental ones, which help to master pedagogical skills. The conditions of the organization of educational process, defined by psychological, didactic aspects of activization of educational activity were analyzed. The classification of students' cognitive activity in the unity of its types was substantiated. The analysis of the control-regulatory component of didactic structures was carried out, which assumes the use of qualitative and quantitative characteristics of the efficiency of students' cognitive activity.

Taking into account the standpoint of personality-oriented learning characteristics that reflect the realization of personal capabilities and the degree of creativity in the process of vocational training were revealed. The importance of the ability to reflect, which is of great importance in the professional activities of future teachers; conditions for the formation of reflection in the process of vocational training. The main components of vocational training of future technologies teachers were defined: their theoretical and practical training in the process of training in the cycle of general technical disciplines, all types of training and production practice and optional classes.
\end{abstract}

Key words: technologies teacher, educational process, vocational training, cognitive activity, didactic aspects, generalization, systematization.

Стаття надійшла до редакиії 10.05.2020 p. 